\title{
WYKRYWANIE USZKODZEŃ WĘZLÓW RAMY STALOWEJ Z WYKORZYSTANIEM METODY CYFROWEJ KORELACJI OBRAZU
}

\begin{abstract}
W artykule pokazano możliwość zastosowania metody wizyjnej, jaką jest metoda cyfrowej korelacji obrazów (ang. Digital Image Correlation, DIC), do identyfikacji uszkodzeń w konstrukcjach budowlanych na przykładzie stalowej ramy dwukondygnacyjnej. W tym celu przeprowadzono pomiary przemieszczeń metodą DIC na wybranym fragmencie ramy obciążonej dynamicznie, dla różnych wariantów uszkodzenia wprowadzanego w połączeniach dolnego rygla ze słupami. Przeanalizowano otrzymane wartości przemieszczeń. Wyniki przeprowadzonego eksperymentu wskazują na duży potencjał w zastosowaniu metody DIC, jako alternatywnej metody pomiarowej, pozwalającej pozyskać dane wykorzystywane np. do detekcji uszkodzeń konstrukcji. W pracy pokazano również możliwość zastosowanie prezentowanego systemu do pomiarów szybkozmiennych.
\end{abstract}

Słowa kluczowe: cyfrowa korelacja obrazu (DIC), metody wizyjne, pomiar bezkontaktowy, detekcja uszkodzeń, eksperymentalna analiza modalna

\section{Wprowadzenie}

Metody bezkontaktowe, w tym metody wizyjne, są coraz częściej stosowane w badaniach laboratoryjnych konstrukcji budowlanych. Tendencja taka wynika przede wszystkim z potrzeb praktycznych oraz $\mathrm{z}$ bardzo intensywnego w ostatnich latach rozwoju technologii informacyjnej, systemów komputerowych, elektroniki i urządzeń optycznych. Zastosowanie metod bezkontaktowych pozwala na uniknięcie problemów pojawiających się w badaniach tradycyjnymi metodami pomiarowymi, na przykład z mocowaniem czujników pomiarowych na konstrukcji. Eliminuje również bezpośredni wpływ aparatury na uzyskane

${ }^{1}$ Autor do korespondencji / corresponding author: Barbara Turoń, Politechnika Rzeszowska, Katedra Mechaniki Konstrukcji, ul. Poznańska 2, 35-959 Rzeszów; tel. 178651622; bturon@prz.edu.pl.

${ }^{2}$ Dominika Ziaja, Politechnika Rzeszowska, Katedra Mechaniki Konstrukcji, ul. Poznańska 2, 35-959 Rzeszów; tel. 178651618; dziaja@prz.edu.pl.

${ }^{3}$ Bartosz Miller, Politechnika Rzeszowska, Katedra Mechaniki Konstrukcji, ul. Poznańska 2, 35-959 Rzeszów; tel. 178651623; bartosz.miller@ prz.edu.pl. 
wartości mierzonych wielkości, a także pozwala na wykonywanie pomiarów w trudnych warunkach np. na badanie elementów konstrukcji budowlanych, do których nie ma bezpośredniego dostępu albo jest on utrudniony. Metody bezkontaktowe pozwalają na znaczne uproszenie procedury badawczej, skracają czas potrzebny na przygotowanie eksperymentu, jak również pozwalają na zautomatyzowanie analizy wyników. Wśród metod wizyjnych można wyróżnić metodę cyfrowej korelacji obrazu (ang. Digital Image Correlation, DIC), stosowaną do pomiarów przemieszczeń i odkształceń. Prezentowana w artykule metoda może również stać się alternatywą dla innej, dobrze znanej już bezkontaktowej metody pomiarowej, jaką jest wibrometria laserowa [1]. W przypadku wibrometru precyzyjny pomiar ruchu punktów w płaszczyźnie, na jakiej są one zlokalizowane, możliwy jest tylko przy korzystaniu z zestawu trzech głowic laserowych. Konieczność synchronizacji głowic oraz ilość niezbędnej aparatury znacząco komplikuje wykonanie pomiarów. Warto wspomnieć, że do zarejestrowania ruchu punktów metodą DIC wystarczy tylko jedna kamera. Inną ważną zaletą systemów DIC jest możliwość wykonywania pomiaru dla wielu punktów w dokładnie tym samym momencie. $\mathrm{W}$ trakcie badań $\mathrm{z}$ wykorzystaniem wibrometru laserowego w danej chwili można pomierzyć parametry wyłącznie jednego punktu.

Sprawdzenie możliwości wykorzystania metody cyfrowej korelacji obrazu do detekcji uszkodzeń w konstrukcjach budowlanych daje szansę na rozwój nowych metod wykrywania uszkodzeń w konstrukcjach. Identyfikacja uszkodzeń jest bardzo ważnym zagadnieniem z punktu widzenia bezpieczeństwa konstrukcji (temat identyfikacji uszkodzeń podejmowany był w licznych pracach naukowych np. [2, 3, 4]), toteż w artykule podjęto próbę zastosowania DIC do detekcji uszkodzeń w węzłach ramy stalowej. W pracy przedstawiono wyniki badań laboratoryjnych zrealizowanych w Katedrze Mechaniki Konstrukcji Politechniki Rzeszowskiej.

\section{System cyfrowej korelacji obrazu}

Cyfrowa korelacja obrazu jest jedną z metod pomiarowych opartych na systemach optyczno-elektronicznych. Umożliwia ona bezkontaktowy pomiar przemieszczeń i odkształceń poprzez korelację obrazów cyfrowych badanego obiektu zarejestrowanych podczas jego odkształcania się i/lub przemieszczania. Podstawowymi elementami systemu cyfrowej korelacji obrazu są kamery oraz komputer ze specjalistycznym oprogramowaniem, które pozwala na rejestrację obrazów, ich analizę, wizualizację uzyskanych wyników oraz eksport danych [5, 6]. Pomiar przemieszczeń i odkształceń metodą DIC w zależności od liczby zastosowanych kamer może odbywać się na płaszczyźnie lub w przestrzeni trójwymiarowej. Dla próbek płaskich można stosować systemy z jedną kamerą, które umożliwiają tzw. dwuwymiarową cyfrową korelację obrazu, a więc pomiar w płaszczyźnie równoległej do płaszczyzny obrazu obserwowanego przez kamerę. W celu uzyskania wyników badań w przestrzeni trójwymiarowej konieczne 
jest zastosowanie co najmniej dwóch kamer, które będą rejestrowały obiekt z dwóch różnych kierunków [7, 8].

Pomiar metodą DIC polega na wykonaniu zdjęcia badanego obiektu przed jego obciążeniem oraz zarejestrowaniu serii zdjęć po obciążeniu obiektu. Zarejestrowane obrazy są zapisywane i analizowane przez specjalistyczne oprogramowanie. Jeden $\mathrm{z}$ obrazów wybierany jest jako referencyjny (najczęściej jest to zdjęcie obiektu wykonane przed jego obciążeniem). Na obraz ten nakładana jest wirtualna, regularna siatka punktów. Każdy punkt siatki wyznacza środek kwadratowego regionu obrazu wielkości od kilkunastu do kilkudziesięciu pikseli. Wszystkie wyznaczone na referencyjnym obrazie regiony tworzą razem siatkę regionów korelacji (rys. 1) [6,8]. Regiony te mają przyporządkowane współrzędne ich położenia w określonym układzie współrzędnych (może być to układ związany z kamerą, określony podczas kalibracji systemu na podstawie pierwszego zarejestrowanego zdjęcia tablicy kalibracyjnej lub układ zadany przez użytkownika systemu). Dzięki losowemu wzorowi punktów naniesionemu przed badaniem na powierzchnię badanego obiektu możliwe jest rejestrowane i analizowanie zmiany kształtu i położenia poszczególnych regionów w trakcie obciążania obiektu. Oprogramowanie systemu DIC odnajduje pozycję każdego regionu korelacji z obrazu referencyjnego na wszystkich pozostałych zarejestrowanych obrazach. Dla każdego regionu obliczane są wektory przemieszczeń, a na ich podstawie wyznaczane są wartości odkształceń $[6,8]$.

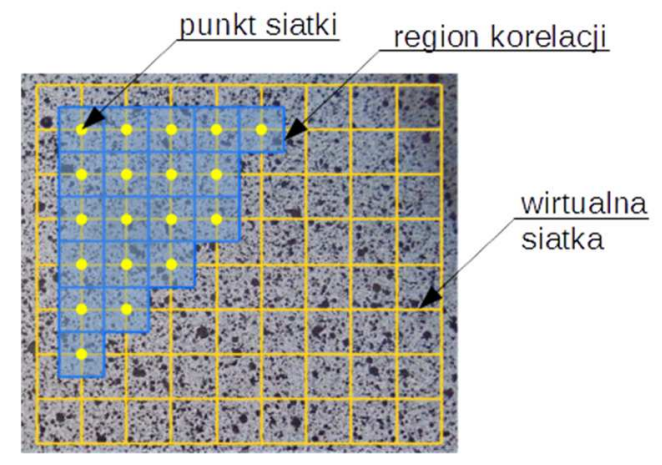

Rys. 1. Wirtualna siatka punktów i regionów korelacji, na podstawie [6]

Fig. 1. Virtual grid of points and facets grid, based on [6]

Przykładem systemu pomiarowego, którego działanie opiera się na metodzie cyfrowej korelacji obrazu, jest system Q-450 firmy Dantec Dynamics. Podstawowe elementy systemu to dwie kamery cyfrowe, przenośny komputer z oprogramowaniem Istra 4D, urządzenie wyzwalająco-sterujące synchronizujące układ pomiarowy oraz tablice kalibracyjne. Pomiar przemieszczeń i odkształceń systemem Q-450 składa się z kilku etapów: przygotowania próbki do bada- 
nia poprzez stworzenie na jej powierzchni losowego wzoru punktów, ustawienia stanowiska pomiarowego oraz skonfigurowania sprzętu, kalibracji układu z wykorzystaniem specjalnie do tego przeznaczonych tablic kalibracyjnych, pomiaru właściwego a więc rejestracji obrazów podczas obciążania obiektu, analizy zapisanych zdjęć opartej na korelacji oraz wizualizacji uzyskanych wyników [6].

System DIC Q-450 realizuje obliczenia za pomocą algorytmu korelacji w oparciu o pseudo-afiniczną transformację współrzędnych regionów korelacji wyznaczonych na obrazie referencyjnym badanego obiektu, z uwzględnieniem parametrów transformacji: translacji, rozciągnięcia, ścinania i dystorsji. Transformowane współrzędne można wyrazić wzorami [7, 8]:

$$
\begin{aligned}
& x_{t}\left(a_{0}, a_{1}, a_{2}, a_{3}, x, y\right)=a_{0}+a_{1} x+a_{2} y+a_{3} x y, \\
& y_{t}\left(a_{4}, a_{5}, a_{6}, a_{7}, x, y\right)=a_{4}+a_{6} x+a_{5} y+a_{7} x y,
\end{aligned}
$$

gdzie: $x, y$-współrzędne przed transformacją,

$x_{t}, y_{t}$ - współrzędne po transformacji,

$a_{1}, a_{2}, a_{3}, a_{4}, a_{5}, a_{6}, a_{7}-$ parametry transformacji (rys. 2).

Parametry transformacji są tak dobierane, aby zminimalizować różnicę pomiędzy oryginalnym wzorem punktów $G(x, y)$, a zdeformowanym wzorem występującym na kolejnym analizowanym obrazie $G_{t}(x, y)$, z uwzględnieniem korekty fotogrametrycznej $[7,8]$ :

$$
\min _{a_{0}, \ldots, a_{7}, g_{0}, g_{1}} \sum_{x, y}\left\|G(x, y)-G_{t}(x, y)\right\|,
$$

gdzie:

$G_{t}(x, y)=g_{0}+g_{1} G\left(x_{t}(x, y), y_{t}(x, y)\right)$,

$g_{0}, g_{1}$ - parametry oświetlenia.
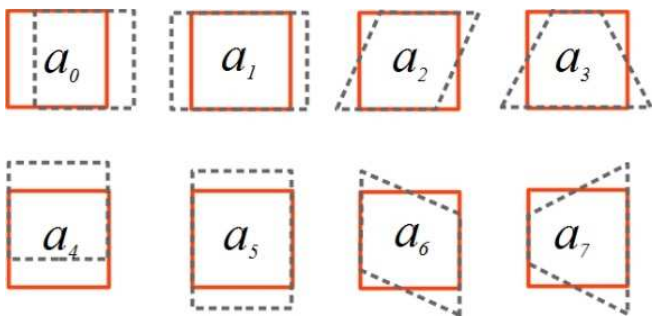

Rys. 2. Parametry transformacji, na podstawie $[6,7]$

Fig. 2. Transformation parameters, based on $[6,7]$ 


\section{Badania laboratoryjne}

Celem badań była identyfikacja uszkodzeń stalowej ramy w połączeniach rygla ramy ze słupem poprzez analizę przemieszczeń zarejestrowanych systemem cyfrowej korelacji obrazu dla wybranego fragmentu rygla ramy.

Badaniu poddana została dwukondygnacyjna rama portalowa wykonana z kształtowników stalowych o stałym przekroju identycznym dla rygli i słupów. Do budowy ramy zastosowano dwuteownik IPE 80 ze stali S355, długości elementów w osiach wynosiły 1,6 m (rys. 3). Połączenie rygla ze słupem wykonane zostało za pomocą 8 śrub M8 klasy 8.8 .

Pomiary systemem cyfrowej korelacji obrazu wykonane zostały dla fragmentu rygla dolnego ramy. Wybrany do analizy obszar rygla miał wymiary $100 \mathrm{~mm} \times 50 \mathrm{~mm}$ i położony był centralnie względem osi symetrii ramy. Badany fragment konstrukcji przedstawiono na Rys. 3.

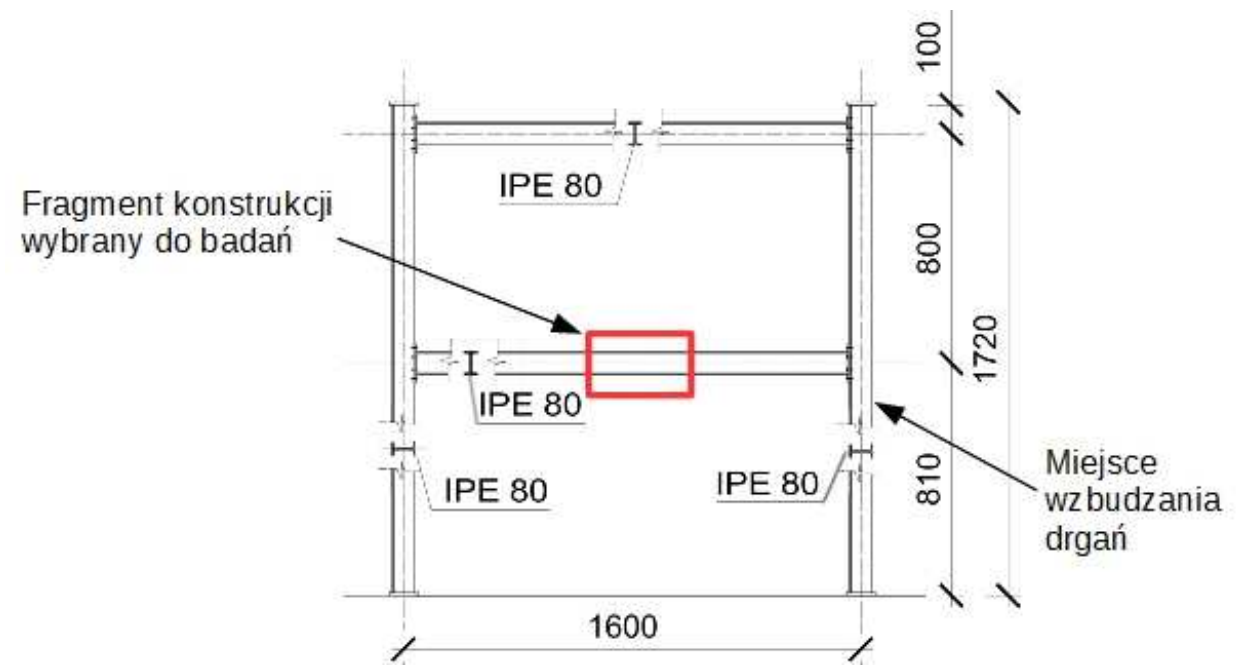

Rys. 3. Schemat ramy stalowej z zaznaczonym fragmentem wybranym do badań

Fig. 3. Steel frame scheme with section selected for testing

Stanowisko pomiarowe do badań laboratoryjnych składało się ze wzbudnika firmy The Modal Shop, Inc. Model 2100E11, zamocowanego na dodatkowej konstrukcji wsporczej w sąsiedztwie ramy, wzmacniacza sygnału, wielokanałowego rejestratora/analizatora LMS Scadas Mobile, komputera pomiarowego z oprogramowaniem Siemens LMS Test.Lab 15 z modułem MIMO FRF Testing oraz z systemu cyfrowej korelacji obrazu Q-450 firmy Dantec Dynamics. Stanowisko laboratoryjne przygotowane do badań przedstawiono na rys. 4.

Wybrany do badań fragment rygla ramy stalowej został dokładnie oczyszczony. Następnie na jego powierzchnię nałożono białą farbę, tworząc w ten spo- 
sób warstwę bazową, na której metodą natryskiwania naniesiono losowy wzór czarnych punktów. Systemem wizyjnym wykonano kilkukrotny pomiar przemieszczeń na powierzchni analizowanego fragmentu rygla ramy przy zastosowaniu jednej kamery, tzw. DIC-2D, dla różnych stanów ramy: I wariant - rama nieuszkodzona, II wariant - uszkodzone dwa węzły ramy tj. połączenie słup dolny rygiel ramy z prawej i lewej strony, III wariant - uszkodzony jeden węzeł ramy tj. połączenie słup - dolny rygiel ramy $\mathrm{z}$ prawej strony, IV wariant uszkodzony jeden węzeł ramy tj. połączenie słup - dolny rygiel ramy z lewej strony. W sytuacji bez uszkodzenia wszystkie łączniki, we wszystkich czterech połączeniach rygiel-słup, zostały dokręcone takim samym momentem.

Pomiar przemieszczeń na powierzchni wybranego do badań fragmentu ramy przeprowadzono podczas obciążenia dynamicznego. Drgania konstrukcji wzbudzano wymuszeniem harmonicznym (sinusoidalnym) o częstotliwości zbliżonej do częstotliwości drgań swobodnych ramy tj. 106 Hz. Rejestracja obrazów przeprowadzona została w sposób ciągły przy częstotliwości nagrywania obrazów $2120 \mathrm{~Hz}$ (tj. 2120 zdjęć na sekundę).

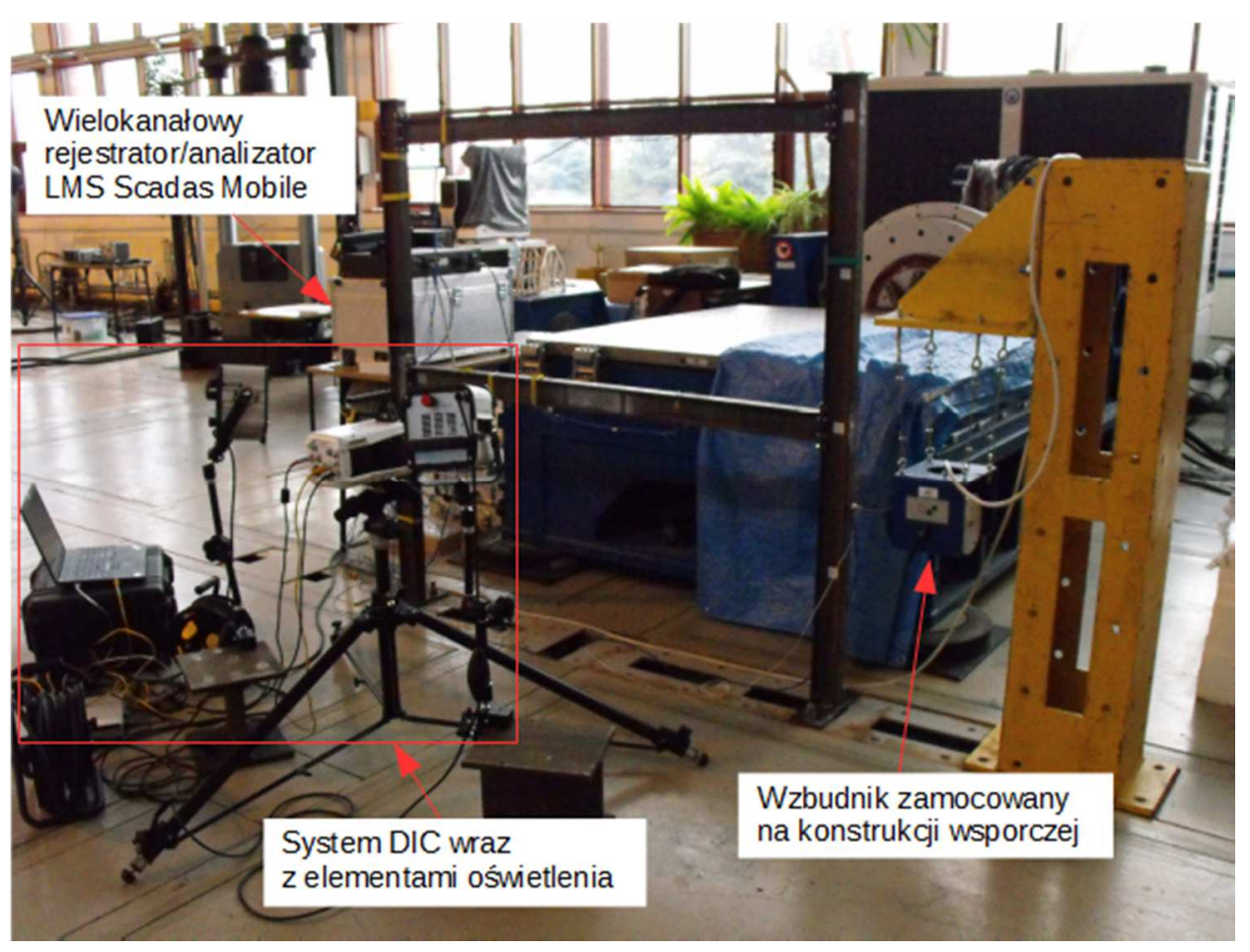

Rys. 4. Stanowisko pomiarowe

Fig. 4. Measurement set-up 


\section{Analiza wyników}

System cyfrowej korelacji obrazu pozwolił na jednoczesny pomiar przemieszczeń 4371 punktów znajdujących się na powierzchni wybranego fragmentu rygla ramy (punkty te zostały automatycznie zdefiniowane przez oprogramowanie systemu DIC). W każdym punkcie uzyskano z pomiarów wartości przemieszczeń w dwóch kierunkach: $x$ (wzdłuż osi poziomej rygla) i $y$ (w kierunku prostopadłym do osi poziomej rygla) oraz wartość przemieszczenia całkowitego, dla ramy nieuszkodzonej oraz trzech różnych wariantów uszkodzenia ramy. Wirtualną siatkę punktów nałożoną na badaną powierzchnię rygla oraz układ osi $x y$ pokazano na rys. 5 .

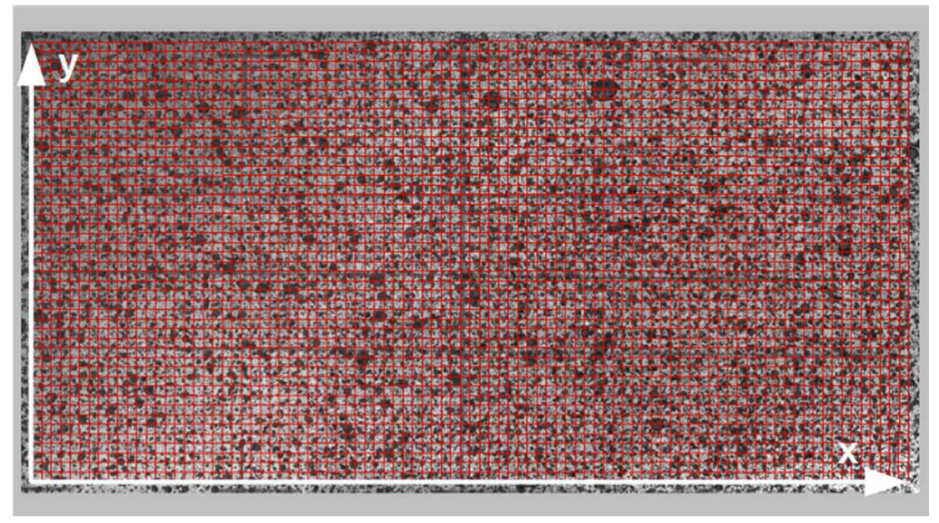

Rys. 5. Wirtualna siatka punktów oraz układ osi $x y$

Fig. 5. Points virtual grid and $x y$ axes

W programie Istra 4D, stanowiącym część systemu DIC Q-450, wygenerowane zostały kolorowe mapy przemieszczeń, pokazujące polowe rozkłady składowych przemieszczenia $x$ i $y$ oraz przemieszczenia całkowitego w czasie badania. Poszczególne mapy przedstawiają wartości przemieszczeń wszystkich punktów znajdujących się na badanej powierzchni rygla ramy w danej chwili. Mapy zostały stworzone dla każdej $0,00047 \mathrm{~s}$ badania tj. co $470 \mu \mathrm{s}$. Każda chwila, w której zarejestrowano pojedynczy obraz rygla ramy, na podstawie którego uzyskano mapy przemieszczeń, nazwano dalej krokiem pomiarowym.

$\mathrm{W}$ programie Istra 4D dla każdej mapy określone zostały maksymalne, minimalne i średnie wartości przemieszczeń. Z pomiarów otrzymano również obrazy pokazujące przemieszczenia całkowite punktów badanej powierzchni za pomocą wektorów oraz poprzez deformację wirtualnej siatki nałożonej na powierzchnię analizowanego fragmentu rygla ramy.

Przykładowe mapy przemieszczeń pokazano na rys. 6, 7 oraz 8. Są to mapy dla II wariantu uszkodzenia ramy i kroku pomiarowego, w którym średnia wartość przemieszczenia na kierunku $x$ na badanej powierzchni była maksymalna. 


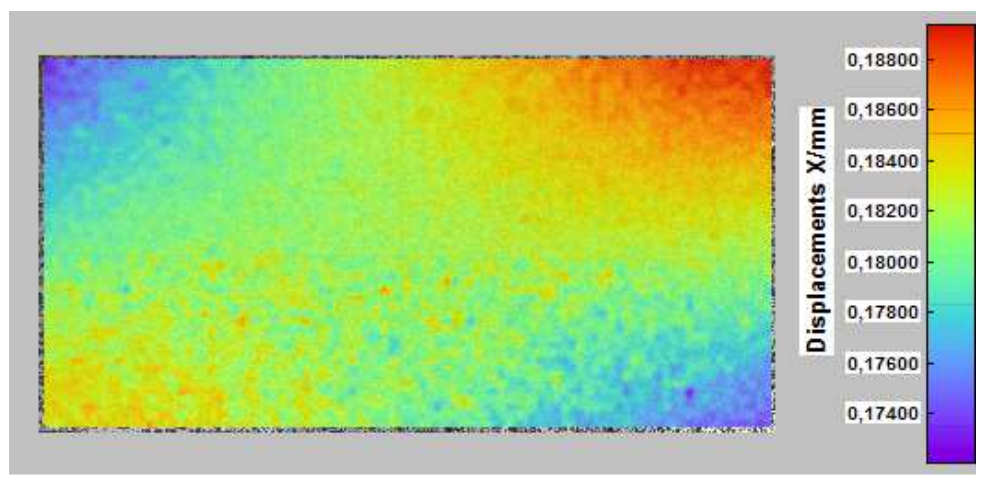

Rys. 6. Mapa przemieszczenia $\delta x$ dla wariantu II uszkodzenia ramy

Fig. 6. $\delta x$ displacement map for II damage variant

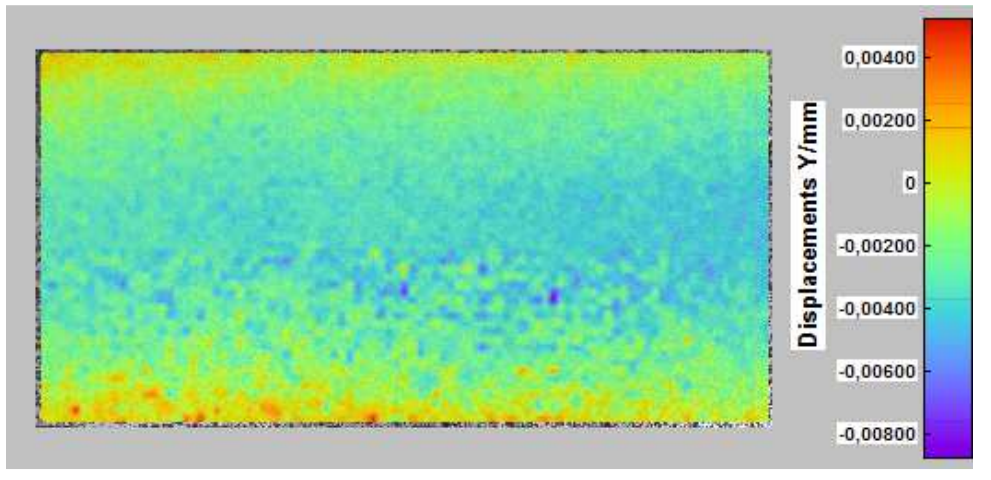

Rys. 7. Mapa przemieszczenia $\delta y$ dla wariantu II uszkodzenia ramy

Fig. 7. $\delta y$ displacement map for II damage variant

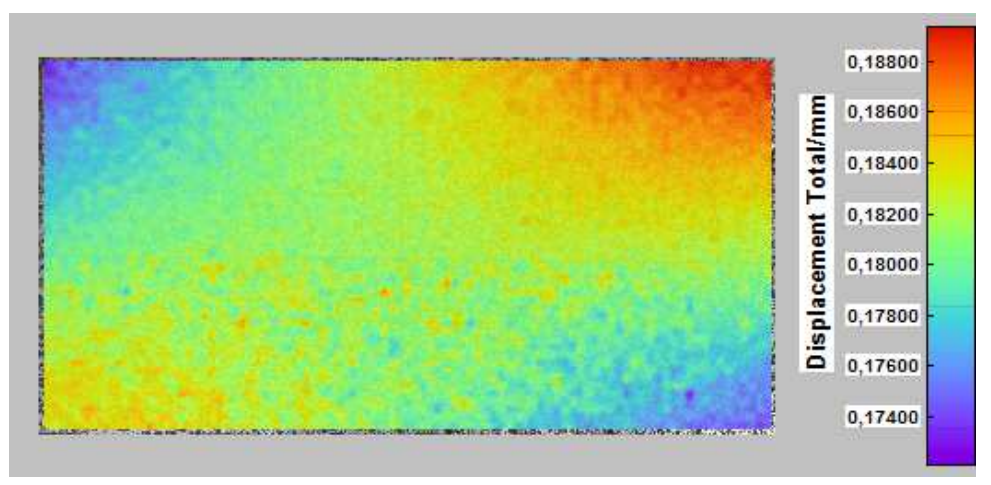

Rys. 8. Mapa przemieszczenia całkowitego $\delta$ dla wariantu II uszkodzenia ramy

Fig. 8. Total $\delta$ displacement map for II damage variant 
W celu identyfikacji uszkodzenia ramy porównano mapy przemieszczeń w kierunku poziomym $(\delta x)$ oraz w kierunku pionowym $(\delta y)$ uzyskane na badanej powierzchni rygla dla czterech wariantów uszkodzenia. Analizę porównawczą przeprowadzono dla wybranych kroków pomiarowych, począwszy od kroku, w którym średnia wartość przemieszczenia całkowitego osiągała maksimum (krok ten w dalszej części artykułu będzie numerowany jako krok pierwszy). $\mathrm{Na}$ rys. 9 pokazano przykładowe wykresy przestrzenne przemieszczenia $\delta x$ zarejestrowane systemem wizyjnym dla ramy nieuszkodzonej i trzech wariantów uszkodzenia, dla kroku pomiarowego $\mathrm{nr} 1$. $\mathrm{Z}$ kolei rys. 10 przedstawia przykładowe wykresy przestrzenne przemieszczenia $\delta y$ dla wszystkich czterech rozważanych stanów ramy, dla kroku pomiarowego nr 1. Na wykresach na osi pionowej zaznaczono wartości przemieszczenia odpowiednio na kierunku $x$ dla wykresów z rys. 9 oraz na kierunku $y$ dla wykresów z rys. 10 odpowiadające punktom analizowanego obszaru. Osie poziome opisują położenie punktów w prostokątnym układzie współrzędnych, którego początek znajduje się na przecięciu lewej oraz dolnej krawędzi analizowanego obszaru.
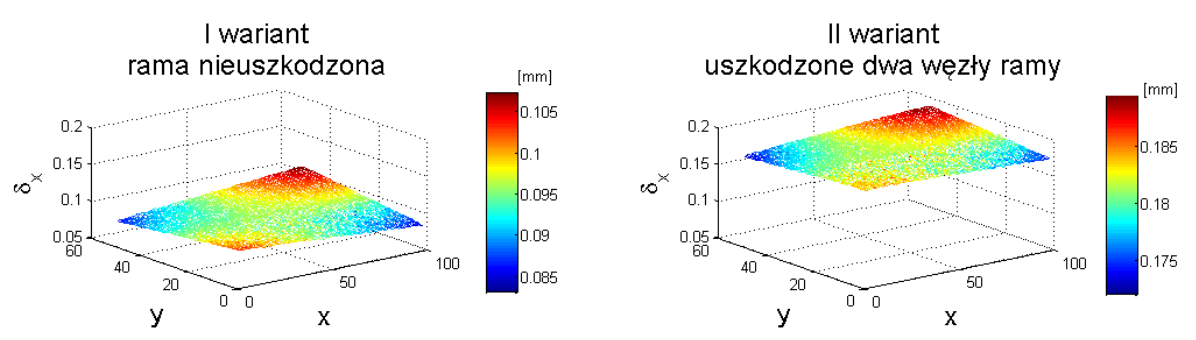

III wariant uszkodzony jeden węzeł ramy z prawej strony
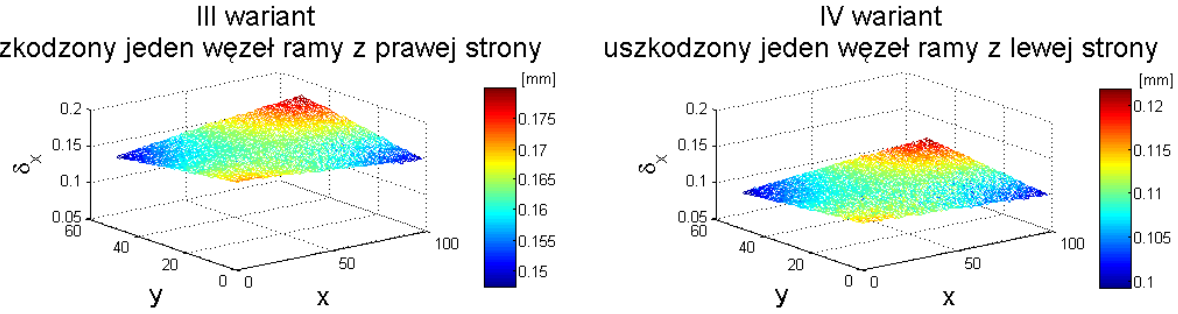

Rys. 9. Wykresy przestrzenne przemieszczenia $\delta x$ dla wariantów I, II, III i IV, dla kroku pomiarowego $\mathrm{nr} 1$

Fig. 9. Spatial plot of $\delta x$ displacement for variants I, II, III and IV, for measurement step no 1 

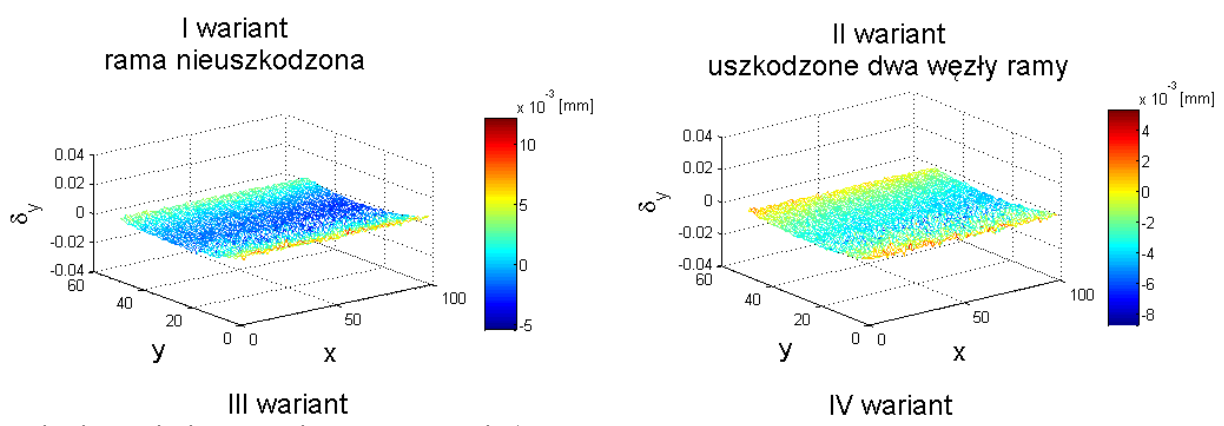

uszkodzony jeden węzeł ramy z prawej strony

uszkodzony jeden węzeł ramy z lewej strony
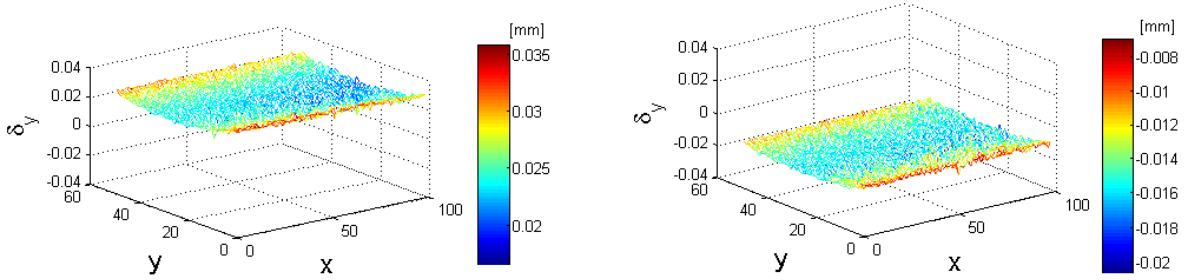

Rys. 10. Wykresy przestrzenne przemieszczenia $\delta y$ dla wariantów I, II, III i IV, dla kroku pomiarowego $\mathrm{nr} 1$

Fig. 10. Spatial plot of $\delta y$ displacement for variants I, II, III and IV, for measurement step no 1

Przeprowadzono kilkukrotną analizę map przemieszczeń. Do pojedynczej analizy wybierano po 20 map (taka liczba map przypadała na czas wykonania jednego pełnego drgania rygla) przemieszczeń $\delta x$, przemieszczeń $\delta y$ i przemieszczeń całkowitych $\delta$ dla czterech rozważanych stanów ramy. W programie Istra 4D dla każdego analizowanego kroku pomiarowego, od $\mathrm{nr} 1$ do $\mathrm{nr} 20$, odczytano wartości średnie przemieszczeń na badanej powierzchni. Krok nr 1 odpowiada chwili, w której średnia wartość przemieszczenia całkowitego na badanej powierzchni rygla jest maksymalna.

$\mathrm{Na}$ podstawie zależności występujących między wartościami średnimi przemieszczeń $\delta x$ i $\delta y$ można jednoznacznie określić rodzaj uszkodzenia ramy. Zależności te przedstawiono w postaci wykresów dla czterech wariantów na rys. 11. Na osi poziomej opisano numerami od 1 do 20 kolejne kroki pomiarowe, w których analizowano mapy przemieszczeń, a na osi pionowej przedstawiono średnie wartości przemieszczeń wyrażone w mm. 

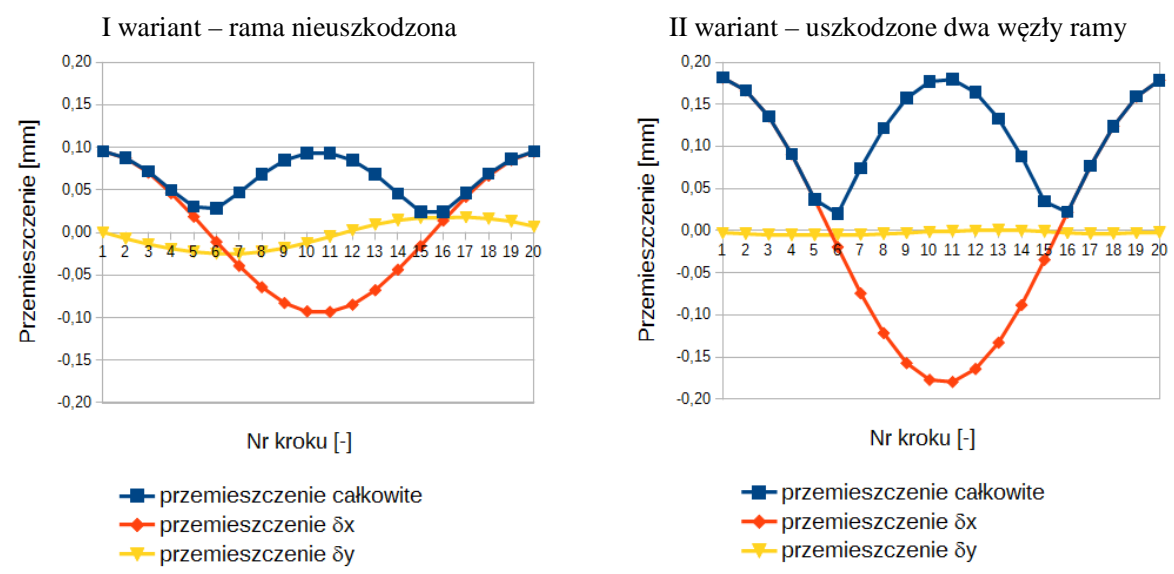

III wariant - uszkodzony jeden węzeł ramy z prawej strony

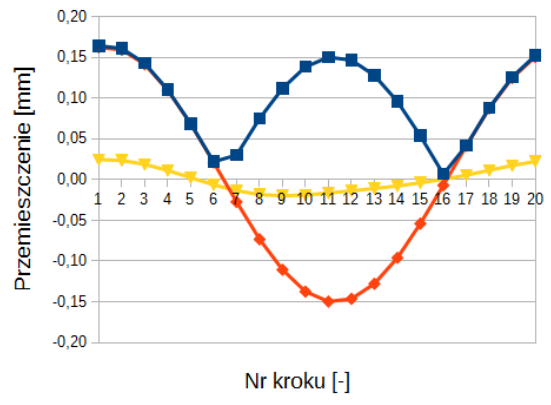

IV wariant - uszkodzony jeden węzeł ramy z lewej

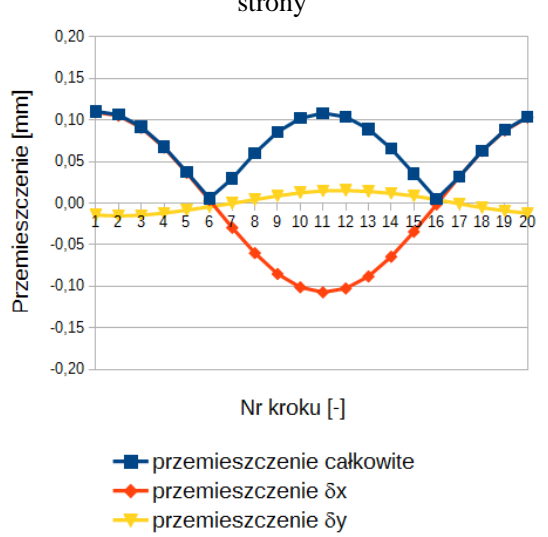

Rys. 11. Wykresy średnich wartości przemieszczeń na badanej powierzchni rygla dla 20 kolejnych kroków pomiarowych, dla wariantów I, II. III i IV

Fig. 11. Plots of mean displacement values on the study spandrel beam surface for 20 subsequent measurement steps, for variants I, II, III and IV

W przypadku ramy nieuszkodzonej (wariant I) dla dodatnich wartości przemieszczenia $\delta x$, przemieszczenia $\delta y$ przyjmują wartości zarówno dodatnie jak i ujemne (analogicznie w przypadku ujemnych wartości przemieszczenia $\delta x$ ).

Dla ramy z dwoma uszkodzonymi węzłami (wariant II) średnie wartości przemieszczenia $\delta y$ są zbliżone do zera.

$\mathrm{W}$ przypadku ramy z uszkodzonym węzłem z prawej strony (wariant III) zachodzi następująca zależność: przemieszczenia $\delta y$ przyjmują wartości dodatnie dla dodatnich wartości przemieszczenia $\delta x$, przemieszczenia $\delta y$ przyjmują wartości ujemne dla ujemnych wartości przemieszczenia $\delta x$. 
Dla ramy z uszkodzonym węzłem z lewej strony (wariant IV) zachodzi natomiast zależność: przemieszczenia $\delta y$ przyjmują wartości dodatnie dla ujemnych wartości przemieszczenia $\delta x$, przemieszczenia $\delta y$ przyjmują wartości ujemne dla dodatnich wartości przemieszczenia $\delta x$.

Zależności te są powtarzalne dla wszystkich wykonanych pomiarów i każdych 20 kroków pomiarowych wybranych do analizy i pozwalają nie tylko na wykrycie uszkodzenia ramy, ale również na identyfikację jego rodzaju.

Przedstawione powyżej związki między przemieszczeniami dla poszczególnych wariantów ramy są bardzo dobrze widoczne również na obrazach pokazujących przemieszczenia całkowite punktów badanej powierzchni poprzez zmianę położenia wirtualnej siatki punktów nałożonej na powierzchnię analizowanego fragmentu rygla. W tabeli 1 zestawiono obrazy wirtualnej siatki wygenerowane w programie Istra 4D dla czterech rozważanych stanów ramy oraz dla wybranych kroków pomiarowych (z 20 kroków przypadających na okres drgań rygla do zestawienia wybrano co trzeci).

Tabela 1. Porównanie przemieszczeń wirtualnej siatki punktów dla wariantów I, II, III, IV

Table 1. Comparison of displacements of virtual grid points for variants I, II, III, IV

\begin{tabular}{|c|c|c|c|c|}
\hline $\begin{array}{c}\mathrm{Nr} \\
\text { kroku }\end{array}$ & Wariant I & Wariant II & Wariant III & Wariant IV \\
\hline 1 & & & & \\
\hline 4 & & & & \\
\hline 7 & & & & \\
\hline 10 & & & & \\
\hline 13 & & & & \\
\hline 16 & & & & \\
\hline 19 & & & & \\
\hline
\end{tabular}




\section{Podsumowanie}

Przeprowadzone badania ramy stalowej z wykorzystaniem systemu wizyjnego potwierdzają możliwość zastosowania metody cyfrowej korelacji obrazu jako alternatywnej metody pomiarowej $\mathrm{w}$ zadaniach związanych $\mathrm{z}$ drganiami konstrukcji budowlanych. Wykonanie serii zdjęć metodą DIC umożliwiło obserwację zmian położenia w czasie wszystkich punktów badanego obszaru jednocześnie. Z pomiarów systemem DIC uzyskano mapy przemieszczeń na kierunkach $x$ i $y$ oraz przemieszczeń całkowitych, a ich analiza pozwoliła na identyfikację rodzaju uszkodzenia ramy (symulowanego poprzez rozkręcenie węzłów). $\mathrm{Na}$ podstawie przeprowadzonych badań można zaobserwować, że odpowiedź konstrukcji nieuszkodzonej różni się od odpowiedzi konstrukcji uszkodzonej. Porównanie średnich wartości przemieszczeń $\delta x$ i $\delta y$ pomierzonych na badanym fragmencie rygla ramy w kolejnych krokach pomiarowych umożliwia ocenę, czy uszkodzenia ramy (w postaci rozkręcenia śrub w połączeniach słup-rygiel dolny) są symetryczne, czy niesymetryczne. Zależności opisane w pracy dotyczą jednak tylko analizowanej ramy (układu symetrycznego) i wymagają dalszych badań, np. niezbędne jest przeprowadzenie pomiarów przy wymuszeniu bliskim innej częstotliwości rezonansowej oraz poza częstotliwościami rezonansowymi. Możliwość obserwacji przemieszczeń na całej powierzchni badanego obszaru może być ogromną zaletą w bardziej skomplikowanych przypadkach uszkodzeń.

\section{Literatura}

[1] Ehrhardt D.A., Allen M.S., Yang S., Beberniss T.J.: Full-field linear and nonlinear measurements using Continuous-Scan Laser Doppler Vibrometry and high speed Three-Dimensinal Digital Image Correlation, Mechanical Systems and Signal Processing, 86, 2017, s. 82-97.

[2] Nazarko P., Ziemiański L.: Wykrywanie uszkodzeń konstrukcji z wykorzystaniem fal sprężystych oraz sztucznych sieci neuronowych, Zeszyty Naukowe Politechniki Rzeszowskiej. Mechanika, z. 74 (258), 2008, s. 271-282.

[3] Kowalczyk P., Nowosielska K.: Analiza możliwości wykrywania uszkodzeń konstrukcji za pomocą technik światłowodowych, Prace Instytutu Lotnictwa, nr 6 (201), 2009, s. 87-96.

[4] Kokot S., Zembaty Z.: Wykrywanie i lokalizacja uszkodzeń w konstrukcjach budowlanych za pomocą drgań i analiz numerycznych, Inżynieria i Budownictwo, R. 62, nr 4, 2006, s. 215-218.

[5] Frankovský P., Virgala I., Hudák P., Kostka J.: The use of the digital image correlation in a strain analysis, Int. J. of Applied Mechanics and Engineering, vol. 18, no. 4, 2013, pp. 1283-1292.

[6] Instrukcja obsługi systemu Q-450: Q-450 SYSTEM Operation Manual, Dantec Dynamics, 2013.

[7] Hagara M., Huňady R., Lengvarský P., Bocko J.: Numerical Verification of a Fullfield Deformation Analysis of a Specimen Loaded by Combined Loading, American Journal of Mechanical Engineering, vol. 2, no. 7, 2014, pp. 307-311. 
[8] Trebuňa F., Huňady R., Bobovský Z., Hagara M.: Results and Experiences from the Application of Digital Image Correlation in Operational Modal Analysis, Acta Polytechnica Hungarica, 2013, vol. 10, no. 5, pp. 159-174.

\section{DETECTION OF DAMAGE IN STEEL FRAME JOINTS BY MEANS OF THE DIGITAL IMAGE CORRELATION METHOD}

\section{S u m m a r y}

The paper presents the possibilities of applying the visual measurements (namely Digital Image Correlation method, DIC) in the damage identification of building structures on the example of a two-storey steel frame. For this purpose, displacement measurements were carried out on a selected fragment of the steel frame subjected to a dynamic load, for the various variants of the damage introduced in the column - lower spandrel beam joints of the frame. The obtained displacement values were analyzed. The results of this experiment indicate a high potential of the DIC application as an alternative measurement method, which allows to obtain data used for instance in the damage detection. The paper also shows the possibilities of applying the presented system for fast-change measurements.

Keywords: digital image correlation (DIC), visual methods, non-contact measurement, damage detection, experimental modal analysis

Przestano do redakcji: 06.06 .2017 r

Przyjęto do druku: 30.06 .2017 r. 